\title{
Figurative Representation of Truth in V. Woolf's Fiction
}

\author{
By Natalya Davidko
}

\begin{abstract}
$V$. Woolf's prose is essentially metaphoric and is characterized by the unceasing creation of novel images. The focal point of the current research is figurative representations of the concept of Truth in V. Woolf's fiction. The analysis of mythological, religious and philosophical interpretations of the concept in question, as well as the study of canonical stereotypes of portraying Truth in paintings of different periods and schools let us establish a common cognitive paradigm that supplies basic guiding images. This paradigm is instantiated in $V$. Woolf's truth-related discourses and shapes the ways in which the author visualizes and verbalizes the concept of Truth. The in-depth research into textural peculiarities and semantic content of the discourses demonstrates that, epistemologically, truth metaphorics is based on three cognitive archetypes - Reflection, Light and the Mirror. The diversity of textual representations makes evident the dynamic character of $V$. Woolf's metaphoricity which is engendered by various combinations of the archetypes, masterful use of their symbolic meanings conjoint with elements from other semiotic systems, and changing trends in pictorial art.
\end{abstract}

Keywords: truth, archetype, reflection, light, the mirror

Tell me, pretty looking-glass, Nothing but the truth, I ask. $\left(\right.$ Pushkin $\left.^{1}\right)$
Dou Miroir par double maniere Puestie tu veior oevre pleinere.

[Gentle mirror in two ways You can fully expose everything] (Jean de Condé2)

\section{Introduction}

"There is nothing more necessary than truth, and in comparison with it everything else has only secondary value" (Nietzsche 2015: 344). Nietzschean words resonate with Virginia Woolf's quest for Truth, especially in her later works. In the essay A Room of One's Own written in 1929, she ponders over the essence of truth: "For truth...Y Yes indeed, which was truth and which was illusion? I asked myself. And the willows and the river and the gardens that run down to the river, vague now with the mist stealing over them, but gold and red in the sunlight - which was the truth, which was the illusion about them?" (Woolf 1929a: 17). Truth is complex and elusive, so the writer's telos lies in the search for truth though the road to it is "rugged, more than it seems" (Woolf 1925). Woolf's professional concern is about "how can we combine the old words in new orders...so that they create beauty, so that they tell the truth?" (Woolf 1937). In her explication of Truth Woolf resorts to what is at the disposal of any writer The Metaphor. Woolf's configurations of truth explicatory models are unique,

\footnotetext{
*Assistant Professor, Moscow Institute TOURO, Russia.

${ }^{1}$ (Pushkin 1973: 7). The great Russian poet A.S. Pushkin (1799-1837).

${ }^{2}$ (Condé 1866: 95). French poet of the $14^{\text {th }}$ century (1275-1352).
} 
unexpected, but always telling, which make them interesting for both literary critics and linguists and are the focal point of the current study. V. Woolf's imagery has been subject to multiple studies (Thakur 1965, Bishop 1986, Young 1986, Olk 2014, Johnston 2014). Researchers were interested in such tropes as "windows," "mirrors," "veil," "sea," "landscape," etc.; however, the truth concept has remained in the shadow, which makes the inquiry into it more pressing and promising.

\section{Theoretical Background}

Figurative thought is an exclusive prerogative of human beings, and figurative language has been used to conceptualize human experience through a broad specter of nonliteral linguistic expressions, such as metaphor, metonymy, hyperbole, symbol, allegory, etc. Metaphors have been operating as cognitive tools for millenniums. An early example is an elaborate metaphor by Heraclitus ${ }^{3}$ (535-475 BCE), who presented the Universe as a cosmostadium with Day and Night, Summer and Winter, etc. being race horses and the Sun the Divine Judge (Lebedev 1985). Aristotle (1961) asserted that apart from being only decorative (ornamental function) or rhetoric (persuasive function) elements, new metaphors are coined in pursuit of "truths" about objective reality. However, the $17^{\text {th }}$ century philosophers such as J. Locke, T. Hobbes and some others considered metaphors artificial constructs which "insinuate wrong Ideas and mislead the Judgment" (Locke 1979: 508). In order to get at the "truth of things," Locke advises that one should get rid of any figures of speech, and "lay the naked Ideas in their due order" (Locke 1979: 676).

However, at some point it became clear that metaphors were vestiges of the mythological stage in the development of conscience on the path to logical thinking. "There is a 'metaphoric' at work at the origin of logical thought, at the root of all classification" (Ricoeur 1975: 22). Metaphors got the status of transitional elements, which vanished when a more precise, literal and unambiguous name for a concept was arrived at (Blumenberg 2010: 77-80).

The understanding of inherent language metaphoricity and the cognitive value of metaphors was substantiated and developed in the Cognitive Theory of Metaphors, which holds that the nature of the human conceptual system is fundamentally metaphorical (Lakoff and Johnson 1980). At the core of human cognition lie mental mappings between the unknown and the known, the abstract and the concrete. Epistemologically, the transfer of knowledge fulfills an explicatory function based on complex associative isomorphy. Numerosity of associations testifies to the potentiality of the human mind to integrate multifarious cognitive conceptual content. Thus, metaphors perform a function of disambiguation, bringing to the fore various facets of a complex notion - one at a time - depending on the context, respective epoch, and culture.

\footnotetext{
${ }^{3}$ A pre-Socratic philosopher known for his aphorism "everything flows" meaning the ever-changing Universe.
} 
In the middle of the $20^{\text {th }}$ century, two advocates of unique functions of metaphors in the development of human thought (American and German) advanced identical ideas that metaphors were "the cognitive foundation for systems of thought and world hypotheses" (Pepper 1942: 151) and that they were orienting models in the world or "ways of seeing within which concepts are formed and undergo modifications" (Blumenberg 2010: 5). Pepper called them "root" metaphors and stressed a clear "determinate effect on human inquiry." Root metaphors are cognitively similar to "absolute metaphors" of Blumenberg. Such metaphors characteristically operate at the level of the unconscious and function as "the substructure of thought" supplying images that conceptualize human experience. They are indispensable "foundational elements" because "by providing a point of orientation, the content of absolute metaphors determines a particular attitude or conduct; they give structure to a world" (Blumenberg 2010: 14).

These theories did not get a widespread practical application though they open up fertile areas for research. This approach provides cognitive tools that allow us to study the hidden patterns in the writer's imagination and see metaphorical concepts in the making. Moreover, it exposes conventions typical of a particular period or epoch, which extend beyond individual works or genres, and embrace all areas of human intellectual and artistic activity. Finally, it allows of integrating seemingly eclectic human spiritual and creative practices into one cultural code whose roots go back to cognitive archetypes of which all future metaphorizations are a natural outcome. According to Carl Jung (1969), archetypes, or primordial images, from a psychological point of view, are universal, archaic patterns that exist at the level of the collective unconscious and represent a nebulous dynamic substratum for conceptualizations, which gets specific expression in a culture in the form of archetypal events, figures/characters, themes, and motifs. They are charged with recognizable meaning due to their recurring use within mythical, religious, literary, and philosophical narrative.

Consequently, metaphors are "essentially historical objects whose testimonial value presupposes that the witnesses did not possess, and could not have possessed, a metaphorology of their own" (Blumenberg 2010: 14). The key word in this definition is "historical." That means that metaphors created in poetry or prose by productive imagination of their authors belong to and are, in different degrees, conditioned by a holistically structured background of imagery (expressive cognitive elements of an epoch) encompassing art, literature, philosophy, religion and other forms of human intellection aimed at cognizing the world and understanding one's authenticity. W. Humboldt (Humboldt 1985) insisted that language, literature and art be analyzed in their Totalität as an integrated whole.

The holistic approach postulated by W. Humboldt for a long time had remained ignored and thus unapplied either to linguistic or philological research: art and language had remained distinctly compartmentalized. However, the development of cognitive science in the middle of the past century which positioned itself as an explicitly interdisciplinary field and a more recent development of cognitive semiotics, a "transdisciplinary," research-oriented, theoretical enterprise which advocated a view of cultural analysis as "a generalized linguistic project" with the ultimate aim of providing new insights into the realm 
of human signification and its manifestation in cultural practices (Brandt 2006, Holenstein 2008, Zlatev 2012) opened up new perspectives in studying meaningmaking in general and figurative representations of logical concepts in particular based on ontological pluralism which presupposes different modes of being.

\section{Material and Method}

The interdisciplinary/transdisciplinary approach has laid down the methodological foundation for the current research. We argue that between a traditional cognitive concept and its figurative representations in literary discourse lies a multifaceted layer of aesthetic and cultural entities (generally comprehensible allegories, symbols, tropes, archetypes, etc.) elaborated and accumulated by human creative thought and rational thinking, mystic and mythic, religious and philosophic views of the world over centuries of human development. This layer constitutes a kind of cultural lens through which an artist represents an object in accordance with a concrete historical period/situation, aesthetic and ideological views, general knowledge and personal preferences. In virtue of this layer, multiple designations of the same concept become possible (the ideational function of language), so the task of a researcher who is concerned with the production and interpretation of tropes is to expose and explain of what latent structures an artist constructs models for conceptual representations, be it literary or visual.

Though the interdiscplinry approach is explicitly advocated in modern theories, the studies carried out within this framework are few and rare. Among impactful researches, in the first place, we can name Hans Blumenberg's groundbreaking work devoted to the philosophy of the Enlightenment whose central image and metaphor - "light" as "illuminative underpinnings of the truth that is accessible to man" (Blumenberg 1993: 43) - gets an in-depth scrutiny from different perspectves: philosophical, theological, semantic, hermeneutic which cross and overlap each other. The work is a brilliant example of a historical approach to metaphoric language and reveals subtle historically conditioned changes in the metaphoric semantics of "light" brought about by a new epoch in contrast to antiquity and the Middle Ages. Another interesting work that influenced our methodology is Arts of Wonder by J. Kosky (2012), a book that explores the intersection of religion and the visual arts, showing that religion is still significant to secular culture, that knowledge of "theological conceptuality" deepens our understanding and interpretation of the pictorial art.

Two works which directly concern V. Woolf's literary methods should be mentioned here. One is by D. Young (1986) who analyzed the mythological element in The Waves; the other is an article by E. Clements, an illuminating study of connections between the sonorous art and the novel The Waves. The critic shows how Beethoven's Grosse Fuge (Opus 133) provided a model for a new novelistic form (Clements 2005: 161), which, like its musical counterpart, is characterized by polyphonic and contrapuntal structure. She establishes similarity between the six movements of the fugue and soliloquies of the six characters in the 
novel (Clements 2005: 165). Each character has his/her own theme that is associated with a specific kind of music: the waltz tune for Jinny, the stamping beat for Louis, the heartrending Cavatina for Rhoda. "Musicalized" language is used in describing nature and emotions. Thus, the author concludes that there are two conventionally distinct media (the word and music) integrated in the texture of the novel.

Building on recent advances in the field of interdisciplinary and intermedial studies we had to work out our own analytical procedure with special emphasis on models of cognitive processes in various areas of human intellectual history. The focal point of our research is the concept of Truth and its multiple representations in the works by V. Woolf. In order to give a plausible explanation to such evident versatility and dynamics of V. Woolf's techniques of creating the trope, we had to expose and delineate a paradigm of constituent cognitive attributes of the truth concept across a broad field of knowledge and art. We set the following objectives: for our procedure 1) to analyze the religious meanings of truth;2) to study the philosophical concept of truth; 3 ) to examine visual representations of Truth by painters of different schools and epochs. Drawing on these findings, we propose 4) to review discourses on truth in V. Woolf's fiction with the aim to elicit its configurations and bring out its affinity with what Blumenberg calls "background metaphorics," and, finally, 5) to attempt to give a plausible explanation to its dynamics. To achieve the above mentioned objectives, the interdisciplinary approach is complemented with the cognitive-historical method, critical analysis, and linguistic methods such as close reading, etymological, semantic and discourse analysis.

The material of research is novels, short stories, and essays written at different periods, in which V. Woolf addresses the problem of truth (see the list of references). For studying religious reflections on the truth, we analyzed spiritual insights in the text of the Bible and other devotional writings; in our analysis of philosophical discourse we paid special attention to early philosophers who suggested the founding ideas for the concept later developed in the works of modern philosophers; the set of artworks was chosen on the thematic content depicting various representations of Truth.

\section{The Concept of Truth}

\section{Etymology}

The English word truth (Anglo-Saxon tríewp, tréowp, trýwp) meaning "faith, faithfulness, fidelity, loyalty; veracity, quality of being true" had cognates in Germanic languages, e.g., Old North tryggð, Old Saxon (gi)trûui, Old High German triuwida, derived from Germanic abstract noun *treuwitho, from ProtoGermanic treuwaz "having good faith." The adjective true (Old English triewe treowe) meant "faithful, trustworthy, honest, steady in adhering to promises," had cognates in many Germanic languages, e.g., Old Frisian triuwi, Dutch getrouw, Old High German gatriuwu, German treu, Old Norse tryggr, Danish tryg, Gothic 
triggws all meaning "faithful, trusty." Both words may be traced to PIE * drew-o-, with the root*dru- (tree) "be firm, solid, steadfast." In Sanskrit taru (tree) meant "steadfast as an oak." The meaning "consistent with fact" was first recorded around 1200; that of "real, genuine, not counterfeit" is from late $14^{\text {th }}$ century (EDO). In Anglo-Saxon there was a special word for these senses - só $p$ meaning "genuine, real, not false." For example, Đat hí oncnáwon ðat ðú eart án sóp God [that they should know that you are a real God] (BT). Thus, the concept of truth involves both the quality of "true faith and loyalty" and that of "agreement with facts and reality."

\section{Religious Interpretation of Truth}

The concept of truth has been discussed and debated in religion, philosophy, art, and literature since antiquity. Christian religion views the truth as revealed to us from heaven by God, who is the guide to truth and truth itself (Lactantius 1885: 10). In Scripture, Pilate asks Jesus "What is Truth?" The answer is given in St. John's Gospel who says that Christ told his disciples, "I am the way, and the truth, and the life" (NIV 1984: John 14:6). Faith-based interpretations of truth postulate that Truth is the secret of the Most High God, who created all things, hence it cannot be attained by our own ability and perceptions, but is given to us as a heavenly gift; and the potency of truth is so strong that true believers cannot fail to see it. However, in the $13^{\text {th }}$ century, Thomas Aquinas incorporated intellect in the conception of truth. According to Christian tradition, he assigns truth in the fullest and most perfect sense to God, the Creator. But he also assigns truth to things themselves and endows them with the capacity to produce truth in the intellect. Finally, he assigns truth to the intellect insofar as it can grasp the essence of things. Only in the intellect does truth reach its fullness and completion (Wippel 1989: 295-299). It is not by accident that approximately at this time the word "truth" acquires the meanings of factuality.

\section{Philosophical Interpretation of Truth}

Seneca said that "truth is nothing without reason" (Seneca Lucius Annaeus 2007: letter 76: 36). This idea was amplified in the $16^{\text {th }}$ and $17^{\text {th }}$ centuries which were the turning point in our intellectual history, when knowledge was exalted by the best minds of the epoch. Bacon's "knowledge is power" was transmitted to the new understanding of "truth as knowledge" the result of which is cognition. Bacon, Descartes, Montesquieu, Montaigne emphasize the difficulties and errors that must be overcome in search of the knowledge of truth (Descartes 2005: 6). Locke stressed that reason must be the final judge of truth "If any proposition... which we take for inspired, be conformable to the principles of reason... we may safely receive it for true," If we do not use reason, then "inspirations and delusions, truth and falsehood, will have the same measure, and will not be possible to be distinguished" (Locke 1979: 438-439). Truth is no longer a matter of divine revelation but a result of a person's inquiry, much effort and "honest labor." "Truth, which only doth judge itself, teacheth that the inquiry of truth, the 
knowledge of truth, and the belief of truth, which is the enjoying of it, is the sovereign good of human nature" (Bacon 1909: 7).

Philosophers of different times and schools related truth to language. In the $17^{\text {th }}$ century, Hobbes insisted that truth is a property of propositions. For him, "true and false are attributes of speech, not of things. And where speech is not, there is neither truth nor falsehood. Error there may be, as when we expect that which shall not be, or suspect what has not been: but in neither case can a man be charged with untruth" (Hobbes 1994: 14-15). Almost three centuries later in 1873, Nietzsche emphasized the role of figurative language. "What then is truth? A mobile army of metaphors, metonyms, and anthropomorphisms - in short, a sum of human relations, which have been enhanced, transferred and adorned poetically and rhetorically and after a long use seem solid, canonical, and binding to a nation" (Nietzsche 1989: 250).

V. Woolf distinguishes at least three kinds of truth: God's or gospel truth; literary truth; and home truth (generally unflattering). For her, the only bearers of truth are words. Besides the surface meaning, words contain many sunken meanings which "rouse the imagination, the memory, the eye and the ear" (Woolf 1937). Sunken meanings are suggestive of many things and a writer can use their suggestive power in fostering relations between imagination, representation and truth.

\section{Truth: Cognitive Constituents}

From the writings of theologians and philosophers we can construe the composite schema of the truth concept and single out its constitutive elements that have lasted throughout millenniums. First, Truth is hidden from human eyes. It lies "hidden veiled in obscurity" and in search of truth people have to "wander through inextricable darkness" (Lactantius 1885: 9). According to Democritus, "truth lies at the bottom of a well, the water of which serves as a mirror in which objects may be reflected" or is "submerged in an abyss ${ }^{4}$ and everything in turn is wrapped in darkness" (Long and Sedley 1987: 483).

Linked with Truth is the concept of Light, a significant metaphor in Scripture. The separation of light and darkness in Genesis emphasizes God's dominance over chaos, darkness, and death. In the Bible, light and truth are basically synonyms. "Oh, send out Your light and Your truth!" (NIV 1984: Psalm 43:3), hence expressions shed/cast light, bring to light (English); faire/jeter la lumière sur (French); ein Schlaglicht auf etwas werfen (German); arrojar algo de luz/sacar a la luz (Spanish); belichten (Dutch); gettare luce su (Italian) in many languages. Light's function is to bring forth the truth. "All things are made manifest by the light; for everything that makes manifest is light" (NIV 1984: Ephesians 5:13). Light is also described as wisdom and knowledge. Ancient philosophers call truth "the light of wisdom." So the search of true knowledge is often described as

${ }^{4}$ In prehistoric times the word for abyss denoted something that was unfathomable and mysterious (Cirlot 1978: 365). 
wisdom-seeking or light-seeking. Truth itself emanates light: "The force of the truth itself is so great, that no one can be so blind as not to see the divine brightness presenting itself to his eyes" (Lactantius 1885: 13).

The next attribute of truth is its nakedness. Truth is "a naked and open daylight" (Bacon 1909: 7). An old fable explains the origin of the ancient concept of "nuda veritas." While Truth was bathing in a river, Falsehood stole her/his? clothes. Truth refused to wear the rags Falsehood had left behind and has been going about naked ever since. Truth does not need any adornments, it is only corrupted by embellishments. "Simple and undisguised truth should be more clear, but falsehood should please by means of a splendor not its own. Falsehood is set off and polished with decoration sought from another source" (Lactantius 1885: 69). The metaphor of the naked truth is present in many languages die nackte Wahrheit (German); verdad pura (Spanish); vérité toute nue (French); veritas nuda (Italian).

Finally, a most important role in acquiring the truth is ascribed to the Mirror. The symbolism associated with the Mirror has its roots in Scripture. A very short phrase uttered by Paul calls for interpretation: "For now we see in a mirror dimly, but then face to face. Now I know in part; then I shall know fully" (NIV 1984: 1 Corinthians 13:12). Theologists interpret it as a reference to James's parable of Two Mirrors. A man who looks intently at his natural face in a mirror and then goes away, at once forgets what he was like. But the one who looks into the perfect law, and perseveres,... will be blessed in his doing. (NIV 1984: James 1:22-25). So according to Paul, there are two mirrors - a dim one and a clear mirror. If we look at ourselves in a dim mirror, we see our reflection, but don't get at the essence; we see only a part of a whole. Only a perfect mirror gives us full self-knowledge: if we look properly, we see who we really are (Orr 1915). The flawless mirror (speculum sine macula) was an attribute of the Virgin Mary. The metaphor is found in the Old Testament, "She is a reflection of eternal light, a spotless mirror of the working of God, and an image of his goodness" (NIV 1984: Book of Wisdom 7:26). Thus, the mirror performs a moral function by setting an example of perfection to which all people should aspire.

Philosophers also enlarged on the concept of the mirror. Socrates considered the mirror a tool to "Know Thyself" - the Delphic maxim. The mirror reflects the inner world of a person, with the help of it one could triumph over one's vices and weaknesses. It is given to man so that he might know his soul. Seneca took up Socrates' ideas and cogitated over a question "What did nature mean by giving us real bodies and then ordaining that phantoms [reflections - N. D.] of them also should be visible?" His answer is: "The mirrors were discovered in order that man might know himself. Many benefits have ensued; first, the knowledge of self, after that, devices to secure specific results. The comely man was taught to shun conduct that would degrade him" (Seneca Lucius Annaeus 2007: letter XVII: Liii). It is believed that Socrates gave mirrors to drunkards and Seneca placed mirrors in the hands of angry men to show how unworthy behavior defiled their souls. Nature

\footnotetext{
${ }^{5}$ In some literary sources Truth is described as a man, hence "he" in many translations. But in painting Truth is always a young maiden.
} 
gave man "A clear fountain or a smooth stone which gives each back his image" (Seneca Lucius Annaeus 2014) and the capacity of seeing his own visage in order to guide him through life (Melchior-Bonnet 2002: 106-107). There are many myths, legends and superstitions associated with the mirror, and in all cultures they are associated with the truth.

\section{Truth in Pictorial Art}

The same metaphorical paradigm serves as the guiding substratum in Pictorial Art, which becomes manifest in paintings by different artists of different epochs. A random choice of pictures whose titles contain the word "Truth" allowed us to define repeated motifs and recurrent symbolic elements and images. Roman mythology holds that Veritas was the daughter of Time (Aulus Gellius 2016), that is why the winged figure of Time, sometimes as a gerontic man with sandglass (Annibale Caracci 1584), sometimes as an able-bodied scythe-holding middleaged man (Jean-François Detroy 1733) is present in the pictures; the favorite topos of painters is Father Time saving his daughter and vanquishing Falsehood and Hypocrisy. Truth is depicted as a young maiden, either unclad (Botticelli's recreation of Apelles' Calumny, ${ }^{6}$ 1494-95) or wearing white robes (Francisco Goya 1812-1814) to emphasize her virginity, sincerity and simplicity. Her brilliantly white body emanates light, sometimes there is a sunny halo around her head. In Art, Truth's opponents are personifications of vices such as Ignorance, Suspicion, Slander, Envy, Fraud, but the main adversary is Falsehood who, unlike Truth, is always beautifully attired, wearing a disguise to deceive the naïve and the gullible. Time and Truth, however, triumph over Falsehood who is often portrayed tossed to the ground or trampled under Truth's feet. The picture by the 18th century painter François Lemoyne Time Saving Truth from Falsehood and Envy (1737), completed on the day before his suicide, contains all these symbolic elements, plus an additional one - the deceptive mask in the left hand of Falsehood (Picture 1).

\footnotetext{
${ }^{6}$ Appelles - the famous painter who lived in the $4^{\text {th }}$ century BCE. None of his works has survived, but some were described by Pliny, Lucian, and others.
} 
Picture 1. F. Lemoyne. Time Saving Truth from Falsehood and Envy

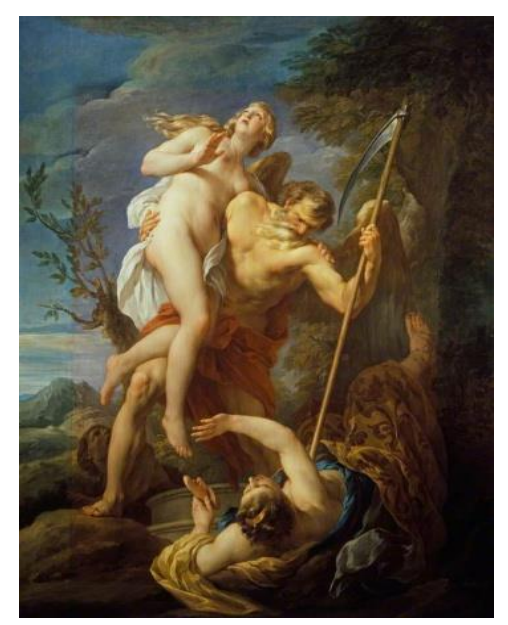

Source: ArtUK

Truth is elusive, and likes to "to hide at the bottom of a holy well" (Caracci 1584, Joy 1892) or in a dark cave (Theodor van Thulden 1657), or in the depth of the forest like in the painting by Jules Joseph Lefebvre (1870), where Truth is emerging from the profound gloom of a forest - in the background dark-brown tree trunks are discernible. The legend of "Truth in the well" is interpreted in various ways by painters. In Caracci's picture, Time has revealed his daughter to the daylight. In the painting by the Irish artist G. W Joy of 1892-93, Truth is inside an old dried up well standing on a small ledge strewn with white lilies, with her hand raised high above her head holding a mirror. Over the edge of the well a little child is peeping. It is to this child that Truth is showing her face in the mirror. In 1895, Jean Gérôme produced a picture portraying wrathful Truth getting out of the well with a whip in her hand to chastise mankind. In 1898, Debat-Ponsan exhibited his allegorical painting (She will not go back) with the same plot of Truth getting out of the well and two figures clad in black attempting to pull her back into it. In many paintings Truth is propertied with a mirror which presents a true image of the world. By the mid-nineteenth century the accepted posture of Truth was a figure holding the mirror high above her head turned to the beholder, ${ }^{7}$ which symbolizes a commitment to reveal the truth to those who really crave for it.

\section{Truth in Impressionism: Fantin-Latour}

When critics discuss V. Woolf's style and manner of writing, they ought not to ignore the influence exercised on her by Impressionism in Art. The 1860s saw a passage to a new style in painting inchoate by the first generation of impressionists among whom are Manet, Monet, Renoir, Legros, and other leading figures. This

${ }^{7}$ It is interesting to note that the first small scale model of the Statue of Liberty by Frédéric Bartholdi, Lefebvre's contemporary, has a similar pose, though she is fully clothed and is holding a torch. 
generation rejected old stereotypes and pursued a new way of expressing reality: endeavoring to grasp changing qualities of light, trying to depict movement, suggesting unusual compositions, and employing visible brush touches. Among this group of painters the works by Fantin-Latour are of special interest for the current research for several reasons: he used mirror images in his work, grappled hard with a new allegorical style, and introduced a novel personification of Truth.

In the late $1850 \mathrm{~s}$, the artist painted his self-portrait as a reflection in the mirror without even reversing the left and right. ${ }^{8}$ This portrait was interpreted and appreciated by critics as the perception of reality "as reflected," an attempt by the young artist to search for his own ego (Miura 2011: 85). Later, he placed this mirror-image in the famous group portrait Homage to Delacroix among other personalities whose portraits were made in the usual way. In this tableau, real images and a mirror image are brought together; perception and introspection are intermingled.

In 1865, Fantin presented for the Salon the painting The Toast: Homage to the Truth, which was so bitterly and probably unjustly criticized that the artist destroyed it after the exhibition. Several fragments of the picture and many preparatory sketches remain, which we can go by to grasp the artist's vision of Truth in the light of new "realist allegory" (Fried 1992: 43), which the artist characterized as "C'est de la phantaisie pure mêlée de réalité" [It is pure fantasy mixed with reality] (Arnoux et al. 2011: 63).

The sketches and drawings detail the elaborate development of the theme: the artist tried giving different turns to his allegorical interpretation of Truth. First, he experimented with the setting. The interior is undoubtedly an artist's studio, but in the initial drawings it opens onto the blue sky and warm light in the upper background, staging a phantasmagoric interplay between interior and exterior realms (Alsdorf 2012) - a device later used by V. Woolf in the short story The Lady in the Looking Glass: A Reflection. A long glass hung in the hall of a country house reflected part of the drawing-room and "a stretch of the garden beyond. One could see a long grass path leading between banks of tall flowers until, slicing off an angle, the gold rim cut it off" (Woolf 1929b: 71). Later, the painter restricted the setting to a closed interior of a studio. The nude female figure holding a mirror high above her head is standing on a platform elevated a little above a group of artists, sculptors, musicians, and writers, who are formally dressed, buttoned up, wearing black suits and top hats. The setting is completely down to earth: a studio and a nude model posing for a portrait - that is how Fantin envisioned allegorical Truth.

The posture of the deity also underwent several transformations with focus selection completely changing the meaning of the picture. In the majority of drawings Truth is standing with her back to the audience facing a group of particular personalities who are toasting her: "A la Vérité, notre idéal!"9 ["To Truth, our ideal!"]. The purport of this composition suggests (and the inscription in

\footnotetext{
${ }^{8}$ This is an old tradition dating to the fifteenth century. Painters adopted the mirror as an indispensable tool for their self-portraits. Among them are: A. Dürer (1484); F. Parmigiano (1524) and others.

${ }^{9} \mathrm{~A}$ note made by the artist in the margin.
} 
the margin supports it) that the absolute priority of Art is to reveal the truth no matter how frightening it can be. In his letter of February 15, 1865, Fantin wrote, "Banquo ${ }^{10}$ ne fit pas tant peur à Macbeth, que la Vérité pour moi." [Banquo did not frighten Macbeth so much as Truth frightens me.] (Arnoux et al. 2011: 68). Several interpretations may be offered to the composition. It may be a reminder to creative minds to depict truly, impartially and open-mindedly the real world; it might be an instance of moral enlightenment or revelation of a particular "truth"; or it could be a moment of introspection - an artist should know the truth about himself. In later sketches, however, Fantin changed the posture of Truth and drew her facing the viewers thus reversing the message and involving the public at large into the quest for the truth (Picture 2).

\section{Picture 2. Henri Fantin-Latour. Sketch for "The Toast! Homage to Truth"}

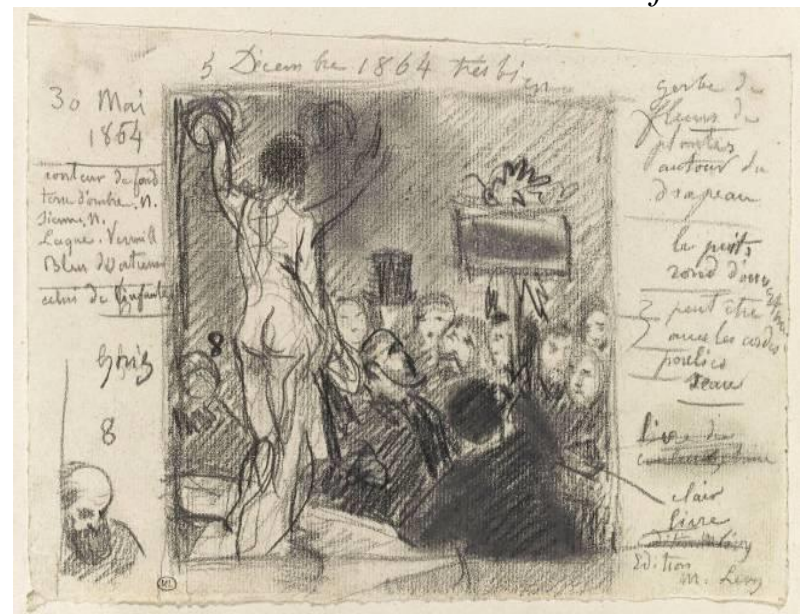

Source: Paris, Département des Arts Graphiques, Musée du Louvre (rf12486)

V. Woolf's interpretation of Truth in Orlando, a phantasmagorical fantasy published in 1928, is, however, closer to that of Gustave Courbet. In his picture The Painter's Studio: A Real Allegory Summing Up a Phase of Seven Years of My Moral and Artistic Life (1855), the artist depicted himself in his studio at his easel with a nude female figure (Truth) standing behind and watching the artist's work over his shoulder. The relationship between the artist and the objective reality seems more personal and selective and is consonant with V. Woolf's philosophical and literary concerns. Woolf portrays in an allegorical way claims on the writer to speak the truth. In her case Truth stands by the inkpot. When obscurity descends and nothing can be seen through its opacity, and the writer is ready to take the pen and write Finis to his work,

"here, alas, Truth, Candour, and Honesty, the austere Gods who keep watch and ward by the inkpot of the biographer, cry No! Putting their silver trumpets to their lips they demand in one blast, Truth! And again they cry Truth! and sounding yet a third time in concert they peal forth, The Truth and nothing but the Truth!" (Woolf 1928: 65).

\footnotetext{
${ }^{10}$ Banquo was a general in King Duncan's army, once a friend of Macbeth but later the adversary Macbeth feared.
} 


\section{The Unwelcome Truth}

Truth is not always welcome. In the picture by Jean-François Detroy Time Unveiling Truth (1733), Father Time unveils his daughter's face, who in her turn tears off the masks of Deceit who is depicted as a frightened-looking woman dressed in dark robes. Aesop's fable is still more illustrative: Truth dwells alone in the wilderness because lies have spread throughout all of human society (Aesop 1957: fable 531), and people do not want to know the truth any longer.

In the old tradition Truth's adversaries were Falsehood, Deceit, Slander, and the like. V. Woolf's choice of antagonists is quite stunning - they are the allegorical Ladies of Purity, Chastity, and Modesty. Their verbalized portrayals make them look as if they had stepped down from canvasses of old Masters.

"First, comes our Lady of Purity; whose brows are bound with fillets of the whitest lamb's wool; whose hair is as an avalanche of the driven snow; and in whose hand reposes the white quill of a virgin goose. Following her, but with a statelier step, comes our Lady of Chastity; on whose brow is set like a turret of burning but unwasting fire a diadem of icicles; her eyes are pure stars, and her fingers, if they touch you, freeze you to the bone. Close behind her, sheltering indeed in the shadow of her more stately sisters, comes our Lady of Modesty, frailest and fairest of the three; whose face is only shown as the young moon shows when it is thin and sickle shaped and half hidden among clouds" (Woolf 1928: 66).

These are a new type of contenders: they do not spread calumny, or defame the innocent, or hide under many disguises, they simply shun the truth, they hide from real life in the highest Alps or in "a cosy nook where there are ivy and curtains in plenty." They cover vice and poverty with their white veils, all things that are frail or dark or doubtful, and repeat their mantra:

"Truth come not out from your horrid den. Hide deeper, fearful Truth. For you flaunt in the brutal gaze of the sun things that were better unknown and undone; you unveil the shameful; the dark you make clear, Hide! Hide! Hide!" (Woolf 1928: 66).

The allegorical figures are a mouthpiece of a "very numerous tribe of the respectable; who prefer to see not; desire to know not; love the darkness" (Woolf 1928: 67), those who worship Wealth, Prosperity, Comfort, and Ease, and knowledge of the truth may introduce dissonance into their otherwise welldesigned and orderly lives.

In the novel To the Lighthouse, the main character, Mr. Ramsay, always spoke the truth no matter how disillusioning it sounded to other people. "What he said was true. It was always true. He was incapable of untruth; never tampered with a fact; never altered a disagreeable word to suit the pleasure or convenience of any mortal being" (Woolf 1927: 5). It exasperated his children and annoyed his wife, who tried to smooth things down. His six-year-old son hated him because the uttered word of truth destroyed "the wonder to which he had looked forward," and deprived him of future joyous prospects. "Had there been an axe handy, a poker, 
or any weapon that would have gashed a hole in his father's breast and killed him, there and then, James would have seized it" (Woolf 1927: 4).

\section{Archetypes as Cognitive Foundations for Truth Metaphorics}

The cultural content analyzed above forms the cognitive base of V. Woolf's metaphorical world. In this part, we address the ways in which the constituent elements are actualized in the writer's works to provide for various representations of truth.

\section{Reflection}

Reflection is an essential archetype intrinsically related with the mythological consciousness whose conceptualizations can be traced back to their roots reified in the myths of Narcissus and Gorgon Medusa. The two myths are different in their semiotic content: the former symbolizes self-adoration and vanity, the latter audacity, valor, and resourcefulness.

Of special interest for the current research is the focal point of these myths Reflection. Etymologically, the word goes back to Old French Réflection from late Latin reflexionem literally meaning "a bending back," derived from the stem of Latin verb reflectere "to bend back, bend backwards, turn away." The word appeared in the English language in late $14^{\text {th }}$ century in reference to surfaces throwing back light or heat; as exemplified in the myth about Narcissus, the original surface was water, and in the myth about Perseus the polished surface of his shield.

In the course of human history, Water has acquired a remarkable symbolic import. The transparency and depth of water were associated with knowledge and wisdom. The very word "eidos" (idea) used by Plato literally means "an image reflected in water or mirror." The reflecting pool was considered to be the mirror of the world (Cirlot 1978: 335-336). Watery surface acquires the significance of the mirror - self-contemplation and revelation. Seneca cites a poet who saw his reflection in the sea water "Lately I saw myself on the shore, When the sea stood calm without a breath of wind" (Seneca Lucius Annaeus 2007: letter XVII: Liii). $\mathrm{V}$. Woolf uses the same image of water reflection, but emphasizes its impartiality and evanescence:

"The river reflected whatever it chose of sky and bridge and burning tree, and when the undergraduate had oared his boat through the reflections they closed again, completely, as if he had never been" (Woolf 1929a: 5).

Reflection in the still water surface is an indispensable element of all paintings featuring "The myth of Narcissus" starting with the miniature in Le Roman de la Rose (c. 1230-1275) and getting its continuation in the famous works by Caravaggio (1597), Poussin (1628), Roubens (1636), Turner (1804) and many 
others. The myth comprises two themes: self-adoration and self-knowledge that brought about Narcissus' early death predicted by Teiresias. ${ }^{11}$ It is not accidental that the two main meanings encoded in the semantic structure of the word "reflection" are: 1) "the image of something as reflected by a mirror or other reflective material"; 2) "thought or opinion after attentive consideration or contemplation; especially, thoughts suggested by truth" (WUD).

Artists also experimented with their own reflections inserting them in pictorial scenes with entirely different subject matter. Jan van Eyck ${ }^{12}$ incorporated his reflection in the mirror on the back wall of the room in his famous The Arnolfini Marriage (1434). Clara Peeters ${ }^{13}$ (1594 - 1657) frequently included miniature self-portraits in the reflection of polished surfaces of goblets, pewter dishes, giltcups, and other vessels she painted. Reflection creates a "duplicate world" (Goscilo 2010: 10) different from the active world of reality.

This facet of reflection is revealed in the Gorgon myth: Perseus avoids petrification by not looking at Medusa directly in the face (her gaze turned any living being into stone), but at her reflection in his shield. The gaze reflected in the shield had no power Medusa possessed in real life, it was a kind of nature morte. The same contrast between real life and its reflection in the mirror is used by $\mathrm{V}$. Woolf in the story The Lady in the Looking-Glass: A Reflection.

"The room that afternoon was full of lights and shadows, curtains blowing, petals falling...And there were obscure flushes and darkenings too... and the room had its passions and rages and envies and sorrows coming over it and touting it, like a human being. Nothing stayed the same for two seconds together" (Woolf 1929a: 75).

But in the looking-glass, there was another kind of reality: "things had ceased to breathe and lay still in the trance of immortality." V. Woolf stresses that "It was a strange contrast - all changing here, all stillness there. One could not help looking from one to the other" (Woolf 1929a: 76).

The device of multiple self-representations, so common in Art, when employed by V. Woolf emphasizes versatility of her characters. The juxtaposition of looking-glass reflection and the real world, is used in the novel Between the Acts, where Isa, a heroine of the novel, is standing "in front of the three-folded mirror, so that she could see three separate versions of her rather heavy, yet handsome, face; and also, outside the glass, a slip of terrace, lawn and tree tops" (Woolf 1941: 7). This scene is cardinally metaphorical. She is both real and unreal, inside the looking glass and outside. She is split in two, so are her feelings.

"Inside the glass, in her eyes, she saw what she had felt overnight for the ravaged, the silent, the romantic gentleman farmer. "In love," was in her eyes. But outside, on the washstand, on the dressing-table, among the silver boxes and tooth-brushes, was the

\footnotetext{
${ }^{11}$ Blind oracle well known in Greek mythology, who prophesized that the boy would live a long life if he "never knows himself."

${ }^{12}$ One of the founders of Early Netherlandish painting (1390?-1441) and one of the most significant representatives of Northern Renaissance.

${ }^{13}$ The earliest significant woman painter of the Dutch Golden Age, one of the earliest group of painters of still lifes and flowers; she also pioneered paintings of fish and game.
} 
other love; love for her husband, the stockbroker. Inner love was in the eyes; outer love on the dressing-table" (Woolf 1941: 7-8).

Light

Reflection is rarely used as a metaphor in its own right, but rather as a concomitant of other symbols - Light and the Mirror. Light is one of the most universal and fundamental archetypes in human history. It is probably the oldest, too. It goes back to prehistoric times when the circle of light cast by the fire in the darkness of the cave was for primeval men space of safety and survival. In the allegory of the Cave, ${ }^{14}$ Plato (428-348 BCE) ascribes to the Sunlight the capacity to illuminate things both physically and mentally. Light helps eyes to see things as they are, and the mind to see the truth: "As the Sun illuminates the visible with light so the idea of goodness illuminates the intelligible with truth, which in turn makes it possible for people to have knowledge" (Plato 2000: 260). Later, light became a symbol of holy image, of the spiritual and the divine, of purity and perfection, of knowledge and wisdom.

Light is used by V. Woolf either as a distinct and independent metaphor with a variety of meanings or in conjunction with Reflection as a truth-revealing expedient. In To the Lighthouse, Light wards off evil spirits and child fears. It is a token of hope. Standing in front of the looking glass, Mrs. McNab, a cleaning woman who comes to sweep up the empty decaying house, tries to discern "some cleavage of the dark, some channel in the depths of obscurity through which light enough issued" to promise her "twined about her dirge some incorrigible hope" (Woolf 1927: 108). Light is capable of reviving visions far removed in time. "Once more, Mrs. McNab, in a ring of light, saw the old gentleman, lean as a rake, wagging his head, as she came up with the washing" (Woolf 1927: 117). For a decade, "some random light from some uncovered star, or wandering ship, or the Lighthouse even" (Woolf 1927: 102) was the only thing that moved inside the deserted and crumbling house, a tiny thread that connected the effervescence of the past with a possible return of life to the old house in the future (Woolf 1927: 92).

In Orlando, V. Woolf modifies the conventional metaphor "Light at the end of the tunnel" meaning "a sign of improvement in a bad situation or that a long and difficult undertaking is coming to its finish" (WUD). V. Woolf applied this metaphor to Orlando's travel in time. Here "the tunnel" means the passing of time and a succession of events and actions, personality metamorphosis and changing epochs, while the light is a torch illuminating the final destination - the present time.

"...as she was thinking this, the immensely long tunnel in which she seemed to have been travelling for hundreds of years widened; the light poured in...And so for some seconds the light went on becoming brighter and brighter, and she saw everything

\footnotetext{
${ }^{14}$ The allegory of the Cave describes prisoners chained to the wall in the cave with no light, whose only realty was shadows; when they got outside and got accustomed to the Sunlight, they saw an entirely different world.
} 
more and more clearly and the clock ticked louder and louder...In fact it was ten o'clock in the morning. It was the eleventh of October. It was 1928. It was the present moment" (Woolf 1928: 147).

In this novel, V. Woolf takes a humorous view of the truth-revealing capacity of light. Orlando (now a woman) is returning to her house in a carriage in company of Mr. Pope. ${ }^{15}$ It is late at night, but streets are already lit with oil-lamps, so periods of pitch darkness are interspersed with short moments of light. "As the light faded, she (Orlando - N.D.) began to feel steal over her the most delicious balm" of illusions (Woolf 1928: 118). V. Woolf satirizes the trite rhetoric and banal conventions unthinkingly repeated by Orlando: "Future ages will think of us with curiosity and envy me" for riding with "the greatest wit in Her Majesty's dominions." However, in the light of a street lamp she thinks, "What a foolish wretch I am! There is no such thing as fame and glory. Ages to come will never cast a thought on me or on Mr. Pope either" (Woolf 1928: 118). In the darkness, she mistakes a hump on a cushion for Mr. Pope's grand forehead. Again comes a torrent of beaten eulogy: "How noble his brow is. What a weight of genius lives in it! What wit, wisdom, and truth...Yours is the only light that burns forever. But for you the human pilgrimage would be performed in utter darkness, without genius we should be upset and undone." (Woolf 1928: 118) In the ring of light beneath one of the street lamps, Orlando realized her mistake. Mr. Pope's forehead is no bigger than another man's. "Wretched man," she thought, "how you have deceived me! When one sees you plain, how ignoble, how despicable you are! Deformed and weakly, there is nothing to venerate in you, much to pity, most to despise" (Woolf 1928: 119). Once they were in complete obscurity again, Orlando's train of thought entered the customary channel of supremacy of men whose images are "set in the sky" and whom women must "serve, honor, and obey." Looking Mr. Pope full in the face in the blazing light, she understands "It is equally vain for you to think you can protect me, or for me to think I can worship you. The light of truth beats upon us without shadow, and the light of truth is damnably unbecoming to us both" (Woolf 1928: 119).

In the above mentioned story The Lady in the Looking-Glass, the intrusion of light, on the contrary, takes a tragic turn. At the beginning of the story, the author writes that very little was known about Isabella, "one could not say what the truth about Isabella was" (Woolf 1929a: 77). She was rich, distinguished, exquisitely dressed, had a faded but fine face and seemed quite satisfied with her comfortable life in a new house stuffed with rarities from exotic countries, taking care of her garden richly planted with flowers; she was a spinster; but there is a subtle implication of past affections, jealousy, passions, and partings. She was reticent. As the narration unravels, there is a recurrent motif that Isabella "did not wish to be known - but she should no longer escape." There must be truth somewhere "either in her house, or in her hidden letters (graven with eternal truth), or in the expression of her eyes." At one moment the truth was nearly brought forth. "The sun would beat down on her face, into her eyes; but no, at the critical moment a

\footnotetext{
${ }^{15}$ Alexander Pope (1688-1744), an $18^{\text {th }}$-century English poet, is best known for his satirical verse and translation of Homer.
} 
veil of cloud ${ }^{16}$ covered the sun, making the expression of her eyes doubtful" (Woolf 1929a: 78); Isabella escaped the exposure when "the lacy clouds veiled her face." In the end, Isabella gets her denouement with the merciless light exposing her real self and her real life. "At once the looking-glass began to pour over her a light that seemed to fix her; that seemed like some acid to bite off the unessential and superficial and to leave only the truth" (Woolf 1929a: 80). V. Woolf resorts to the trite metaphor of nakedness of truth, but replenishes it with a synthesis of imaginary physical nakedness and spiritual emptiness.

"She stood naked in that pitiless light. And there was nothing. Isabella was perfectly empty. She had no thoughts. She had no friends. She cared for nobody. As for her letters, they were all bills. Look, as she stood there, old and angular, veined and lined, with her high nose and her wrinkled neck" (Woolf 1929a: 80).

The unwelcome truth which Isabella refused to recognize was that she was a lonely middle aged woman, devoid of any affections with an empty life which meant to her "futility and evanescence of things."

\section{Mirror}

Before mirrors were invented, other substances had the capacity to reflect objects: polished stones and metals. Rubbing and polishing stones is a wellknown, exceedingly ancient activity of man. In Europe, "holy" stones, wrapped in bark and hidden in caves, have been found in many places; as containers of divine powers they were probably kept there by men of the Stone Age (Franz 1969: 205).

V. Woolf's metaphorical interpretation of the Truth, is to a great extent based on the Mirror archetype. The looking glass is a recurrent motif in many of Woolf's novels and stories and plays an important role in her rhetorical strategies. The symbolism of the mirror is explicitly complex and displays a diversity of meaningful associations.

In art of the late Middle Ages and the Renaissance, mirrors symbolized diametrically opposite qualities: the vices of pride, vanity, and lust (vanitas) and the virtues of truth, justice, and prudence (veritas). Besides being an aesthetic object, mirrors are associated with moral education, sorcery, mystical capacity of exposing hidden realities and predicting the future, showing the real face of the world and the true personality of a character (Goscilo 2010). In the picture Saint Eligius in his Shop ${ }^{17}$ by Peter Christus ${ }^{18}$ (1449), the mirror on the table of the jeweler reflects the outside world and conveys a moral message exposing its vices. It reflects two dandies standing by the window one of whom carries a falcon, a symbol of pride and vanity, a Deadly Sin.

\footnotetext{
${ }^{16}$ Clouds are believed to obscure the immutable quality of higher truth (Cirlot 1978: 50).

${ }^{17}$ The patron Saint of goldsmiths and metal workers; Eligius (588-660) was also a talented goldsmith, chief counselor to the king of France, and a faithful believer who worked for twenty years to convert the population of Flanders to Christianity.

${ }^{18}$ An early Netherlandish painter (1410/1420-1475/1476), noted for his innovations with linear perspective and a meticulous technique.
} 
The theme "Venus at the mirror" is common in paintings by many great artists of the late Middle Ages and Renaissance. Gossaert ${ }^{19}$ (1521), Titian (1555), Rubens (1608) Velazquez (1649) painted the naked goddess admiring herself in the mirror held by Cupid. Such seductive beauty and sexuality was considered sinful by Christian morality and was condemned as vanity (NIV 1984: Ecclesiastes 1: 2). Later the theme got a more secular interpretation. Women of different walks of life and different ages were portrayed in front of the mirror. The artists displayed a variety of attitudes from a mild moralizing character by Paulus Moreelse's ${ }^{20}$ Woman at the mirror (1627) to memento-mori warning by Bernardo Strozzi's ${ }^{21}$ Vanitas or The old Coquette (1615) to biting satire by Goya's ${ }^{22}$ capriccio Till Death (1799).

In V. Woolf's fiction there is only one case of the vanitas use of the mirror. Mrs. Manresa, the wild child of Nature, not much interested in the play, several times takes out her mirror to inspect her cosmetics, attend to her face, her lips and nose. In the other cases the function of the mirror is far more important and related to veritas.

In Orlando, the aging Queen sees in the mirror, "which she kept for fear of spies always by her (an allusion to Virgil's Tale of Mirror ${ }^{23}$ - N.D.), through the open door, a boy - could it be Orlando? - kissing a girl - who in the Devil's name was the brazen hussy? Snatching at her golden-hilted sword she struck violently at the mirror. The glass crashed" (Woolf 1928: 13). The shattered mirror is an omen of calamity. The Queen's days were numbered.

In The Waves, Virginia Woolf's "play poem" (1931), the author contrasts two different characters - Jinny and Rhoda - describing the girls' perception of their own reflections in a looking-glass. "I hate the small looking-glass on the stairs," said Jinny. "It shows our heads only; it cuts off our heads. So I skip up the stairs past them, to the next landing, where the long glass hangs and I see myself entire" (Woolf 1931: 24). Jinny wants integrity and identity. Whereas Rhoda is terrified that she has to assert her stable identity. "That is my face," said Rhoda, "in the looking-glass behind Susan's shoulder - that face is my face. But I will duck behind her to hide it, for I am not here. I have no face" (Woolf 1931: 25); "I hate looking glasses which show me my real face" (Woolf 1931: 26). She cannot cope with the maintenance of identity, and she prefers to have multiple selves and multiple consciousnesses.

The significance of the truth-revealing role of mirrors reaches its apogee in the last novel by V. Woolf Between the Acts. So far, we have been discussing the

\footnotetext{
${ }^{19}$ French-speaking Dutch and Flemish painter (1478-1532), who brought elements of Italian Renaissance to northern Europe.

${ }^{20}$ A Dutch painter of portraits (1571-1638).

${ }^{21}$ A canvas and fresco Italian artist (1581-1644), founder of the Venetian Baroque style.

${ }^{22}$ The most important Spanish artist of the late 18th and early 19th centuries (1746-1828).

${ }^{23}$ Virgil describes a mirror put on a marble tower which protected Rome from enemies spotting them for thirty miles around and was destroyed by Crassus, a dull-witted, greedy emperor. The tale is narrated by Gower, Chaucer, and Dante. Crassus was killed by being made to drink the molten gold.
} 
exposure of private, personal "truths," sought or unsought. On a larger scale, V. Woolf seeks the truth about a community, society and nation as a whole.

The action of the novel takes place in June, 1939; the setting is the English countryside: a house (Pointz Hall), home of the Oliver family, and the nearby village. This is a day of the pageant - a social event attended by the local community and the gentry from the neighboring villages. This year, Miss La Trobe, an amateur playwright, chose a historical theatrical focusing on some landmarks in the English history. The final part of the pageant is called "The present time. Ourselves." "But what could she know about ourselves? She wanted to expose them, as it were, to douche them, with present-time reality" (Woolf 1941: 111) to get at the very spirit of the time.

The climactic scene is essentially impressionistic. Out came the actors "Children? Imps - elves - demons. carrying anything that's bright enough to reflect, presumably, ourselves?" (Woolf 1941: 113). This cavalcade reminds motley fools or court jesters who could speak the truth to the mighty Kings. They stood facing the audience holding "hand glasses, tin cans, scraps of scullery glass, harness room glass, and heavily embossed silver mirrors" to show the spectators their real face. The reflection was fragmented: "Now old Bart...he was caught. Now Manresa. Here a nose... There a skirt...Then trousers only...Now perhaps a face...Ourselves?" (Woolf 1941: 114). The description of mirrors or mirror-like surfaces is repeated several times forming a chain of reflecting gadgets.

And the audience - a wide assortment of people - saw themselves and were shocked at this fractured verisimilitude. "But that's cruel. To snap us as we are, before we've had time to assume...And only, too, in parts...That's what's so distorting and upsetting and utterly unfair" (Woolf 1941: 114). Unfair was it not. It was a moment of epiphany: a disunited society. The audience were indignant to be taken unawares with no time allotted to assume a fitting posture. "People in the back rows stood up to see the fun. Down they sat, caught themselves. What an awful show-up!" The truth was not comforting, but rather unnerving. "All evaded or shaded themselves" (Woolf 1941: 115).

The feeling of disunity and social isolation becomes reinforced by means of the particular structure of the scene and certain narrative devices. The scene is texturally threefold combining body movements, the word, and the sound. First, the message gets a bodily expression through carnivalesque movements of the actors: "Out they leapt, jerked, skipped. Flashing, dazzling, dancing, jumping. Mopping, mowing, whisking, frisking, the looking glasses darted, flashed, exposed" (Woolf 1941: 114). Then the message is put into words and a dictum is pronounced by "a megaphontic, anonymous, loud-speaking" voice:

"Look at ourselves, ladies and gentlemen! Then at the wall; and ask how's this wall, the great wall, which we call, perhaps miscall, civilization, to be built by (here the mirrors flicked and flashed) orts, scraps and fragments like ourselves?" (Woolf 1941: 116).

Superimposed on it is music. The descriptions of music appear again and again in these pages and create a pot-pourri of tunes, motifs, and melodies. "Music began A.B.C.- A.B.C. The tune was as simple as could be"; "Suddenly the tune stopped. 
The tune changed. A waltz, was it? Something half known, half not"; "The tune changed; snapped; broke; jagged. Fox-trot was it? Jazz? Anyhow the rhythm kicked, reared, snapped short. What a jangle and a jingle! What a cackle, a cacophony!" (Woolf 1941: 112). The author mixes dance tunes and popular songs with the anthem; the names of composers look like a haphazard choice: "Fox trot, Sweet lavender, Home Sweet Home, Rule Britannia; Bach, Handel, Beethoven, Mozart or nobody famous, but merely a traditional tune" (Woolf 1941: 116). The cacophonous melodies, scraps of music are in tune with the general atmosphere of fragmentary and kaleidoscopic reality.

Two sounds are at odds with the otherwise bucolic scene - the scenic old house, the cows, the meadows and the view. The first discord is the mechanical, metallic sound of the gramophone. "The machine chuffed in the bushes" (Woolf 1941: 107) repeating "Tick, tick, tick." The audience were unnerved by the monotonous, rhythmic sound and were trying to give a meaning to the empty stage and the non-ending ticking. "The tick of the machine was maddening. There they sat, facing the empty stage while the machine ticked in the bushes. All their nerves were on edge. They sat exposed. The machine ticked. There was no music. Tick, tick, tick went the machine" (Woolf 1941: 108). The metaphoric meaning of the sound produced by the gramophone is quite clear: time was running out for a disunited society.

The other disruptive sound is the ominous roar of fighter bombers. "Twelve aeroplanes in perfect formation like a flight of wild duck came overhead. That was the music. The audience gaped; the audience gazed. Then zoom became drone. The planes had passed" (Woolf 1941: 116). That was a different kind of music, the music of war, the flight of bombers over a peaceful countryside being an omen of the imminent disaster. The unsavory truth is a disunited society on the brink of war.

The elaborate choice of stylistic devices among which the most important are repetitions and string-like arrangement of words denoting meaningful notions (movements, sounds, etc.) bring forth the general ambiance of the pageant. They highlight the clues to what the author (V. Woolf alias Miss La Trobe) wanted to convey. "Ourselves" is repeated more than fifteen times within a short space of a few pages. The next meaningful word is "expose" and its derivatives. "All their nerves were on edge. They sat exposed" (Woolf 1941: 111). "The mirror bearers squatted; malicious; observant; expectant; expository" (Woolf 1941: 115). Another phrase that is repeated several times is "Scraps, orts, and fragments." At first, the audience experiences a shock at being reduced to such unsavory description of themselves. Gradually, an understanding comes: "Scraps, orts and fragments! Surely, we should unite?" (Woolf 1941: 119).

The key phrase is "Dispersed are we." There are two episodes in the novel in which the phrase is the focal point of the narrative. First, it appears as a song during the intermission when the spectators were leaving for the barn to have tea. "As they raised themselves and turned about, the music modulated. The music chanted: Dispersed are we. It moaned. It lamented: Dispersed are we, as they streamed, spotting the grass with colour, across the lawns, and down the paths" (Woolf 1941: 60-61). The chain of verbs introducing the melody reminds of a 
music scale rising to a crescendo: the music modulated - chanted - moaned lamented - wailed. The same scene is repeated at the end of the performance bringing the pageant to its climax and close. Now it is not a song, but the spoken word. "Dispersed are we, the gramophone informed them" (Woolf 1941: 177). The verbs used to introduce the speech are: affirmed-asserted-repeated-informed - triumphed, yet lamented-gurgled and ceased.

This is the only truth-revealing scene in the material analyzed which does not mark the end but suggests a continuation. Surfacing from the depth of historical memory a new understanding emerges: "O let us, the audience echoed (stooping, peering, fumbling), keep together...For there is joy, sweet joy, in company" (Woolf 1941: 122). The end of the pageant offers a newly-found hope of a possibility of unification.

There is one metaphoric concept of exquisite beauty in Between the Acts, which is related to truth but only indirectly - the "Lily pool" (inspired by Claude Monet?). "There had always been lilies there, self-sown from wind-dropped seed, floating red and white on the green plates of their leaves" (Woolf 1941: 26). It is a place of epiphany, a place where one cannot tell or even think a lie. From the contemplative depth of the lily pool, "its black heart," phantoms of the unconscious arise to become realities, their numinous significance becomes externalized, and intuitive reasoning finally acquires the form of logical propositions. Lucy, an elderly lady, a true believer, the widowed sister of the owner of Pointz Hall, stops by the lily pool. She is perturbed by the pageant's harsh message and seeks reassurance from the deep waters of the pond. "Ourselves," she murmured. And retrieving some glint of faith from the grey waters, hopefully, without much help from reason,... seeing in that vision beauty, power, and glory in ourselves...she returned to her private vision of beauty which is goodness" (Woolf 1941: 127). And then illumination comes: "we act different parts but are the same" (Woolf 1941: 135).

\section{Conclusion}

W. Humboldt claimed that "all arts are enlaced by one band." All arts have one aim - to elevate fantasy to the maximum height of its vigor and originality (Humboldt 1985: 185). V. Woolf's prose is a dramatic incarnation of this postulate.

For V. Woolf, figurative imagery is the media in which she can communicate her vision of an abstract concept to the reader drawing on cultural archetypes worked out by human consciousness in the course of evolution - Reflection, Light, and Mirror - all having a long individual history of themes, motifs, and mythos, which evoke a multiplicity of "echoes, memories, and associations." The synthesis of these components complemented in some cases by elements from other semiotic systems creates unique metaphoric visualizations, never repeated in her works but "hand-made" for specific rhetoric occasions. We can single out (1) a composite way of their organization when the archetypes are combined to create a new synergic image (A Lady in the Looking Glass); and (2) a drama-like way when different groups of semiotic elements interact to create a scenic image by 
adding music or sound symbolism (e.g., onomatopoeic repetition of the ticking in Between the Acts).

Her figurative representations are novel intellectual insights, on the part of the author, into the essence of the phenomena of Truth integrating additional attributes, nuances or overtones into a concept; they are cognitively significant vehicles of paving venues for unconventional literary conceptualizations.

Close affinity of V. Woolfs prose with pictorial art of which she was a subtle connoisseur becomes evident when we analyze her aesthetics rooted in the cultural conventions of different epochs. Truth in the $18^{\text {th }}$ century (Orlando) is represented by three allegorical figures (Truth, Candor, and Honesty), which was the overwhelming tradition in Art of that and preceding periods; whereas when the setting is the $20^{\text {th }}$ century (Between the Acts) truth-revealing scenes take a clear-cut impressionistic turn. In her prose, verbalization and visualization are fused into one. This implies flexibility of language, too. V. Woolf is in command of both: a conventional narrative form and almost Victorian style with its elaborate, picturesque portrayals, elongated, stringent sentences, lyrical digressions, and a new modernist style with disjoint scenes, broken, half finished sentences, fragmentary, blurred descriptions - all suggestive of visible brush strokes typical of Impressionist painters.

The reconstruction of mythological, philosophical, and religious paradigm of Truth constituents gives insight into the underlying cognitive foundation, which opens up the multitude of representational perspectives for the Artist and reveals striking congruence with Woolf's metaphorics. The diversity of Truth interpretations, their breadth and profundity let us say that V. Woolf mastered the art of thinking in images to perfection and her metaphorical descriptions still remain unsurpassed.

\section{References}

Aesop (1957) Fables. Translated by J Jacobs. In CW Eliot (Eds.), The Harvard Classics: Folklore and Fable; Aesop, Grimm, Anderson, vol. 17, part 1. New York: Collier and Son Corporation.

Alsdorf B (2012) Fellow Men: Fantin-Latour and the Problem of the Group in Nineteenth-Century French Painting. Princeton: Princeton University Press.

Aristotle (1961) Poetics. Translated by SH Butcher. New York: Hill and Wang.

Arnoux M, Gaehtgens T, Tempelaere-Panzani A (Eds.) (2011) La correspondance d'Henri Fantin-Latour et Otto Scholderer (The correspondence of Henri FantinLatour and Otto Scholderer). Paris: Editions de la Maison des Sciences de l'Homme.

Aulus Gellius (2016) The Attic Nights. Translated by JC Rolfe. Delphi Complete Works of Aulus Gellius, vol. 70. Hastings, UK: Delphi Publishing Ltd.

Bacon F (1909) Essays, Civil and Moral of Truth. In CW Eliot (Eds.), The Harvard Classics, vol. 3, part 1. New York: Collier \& Son Company.

Bishop E (1986) Metaphor and the Subversive Process of Virginia Woolf's Essays. Style 21(4): 573-588.

Blumenberg H (1993) Light as a Metaphor for Truth at the Preliminary Stage of Philosophical Concept Formation. In DM Levin (Eds.), Modernity and the Hegemony of Vision, pp. 30-62. Berkeley: University of California Press. 
Blumenberg H (2010) Paradigms for a Metaphorology. Translated by Robert Savage. New York: Cornell University Press.

Brandt PÅ (2006) Form and Meaning in Art. In M Turner (Eds.), The Artful Mind. Cognitive Science and the Riddle of Human Creativity, pp. 171-188. Oxford: Oxford University Press.

Cirlot JE (1978) A Dictionary of Symbols, $2^{\text {nd }}$ ed. London: Routledge.

Clements E (2005) Transforming Musical Sounds into Words: Narrative Method in Virginia Woolf's The Waves. Narrative 13(2): 160-181.

Condé B (1866) Dits et contes de Baudouin de Condé et de son fils Jean de Condé, vol. 2 (Sayings and tales of Baudouin de Condé and his son Jean de Condé), edited by A Scheler. Bruxelles: Devaux.

Descartes R (2005) Discourse on Method and the Meditations. Translated by F Sutcliffe. London: Penguin.

Franz M-L (1969) The Process of Individuation. In CG Jung (Eds.), Man and his Symbols, pp. 158-229. New York/London: Anchor Press.

Fried M (1992) Manet in His Generation: The Face of Painting in the 1860s. Critical Inquiry 19(1): 22-69.

Goscilo H (2010) The Mirror in Art: Vanitas, Veritas, and Vision. Studies in $20^{\text {th }} \& 21^{s t}$ Century Literature 34(2): 282-319.

Hobbes T (1994) Leviathan. Indianapolis: Hackett.

Holenstein E (2008) Semiotics as a Cognitive Science. Cognitive Semiotics 3: 6-19.

Humboldt W (1985) Language and Philosophy of Culture. Moscow: Progress.

Johnston J (2014) Symbolism in Virginia Woolf's Mrs. Dalloway. Retrieved from https:// bit.ly/32heG21.

Jung CG (1969) The Archetypes and the Collective Unconscious, $2^{\text {nd }}$ ed. Translated by G Adler and RF Hull. In W McGuire (Eds.), The Collected Works, vol. 9, part 1. Princeton, N J: Princeton University Press.

Kosky JL (2012) Arts of Wonder. Chicago: University of Chicago Press.

Lactantius (1885) The Divine Institutes. Translated by W Fletcher. In P Schaff (Eds.), Ante-Nicene Fathers: The Writings of the Fathers down to A.D. 325, vol VII. New York: Christian Literature Publishing Co.

Lakoff G, Johnson M (1980) Metaphors We Live By. Chicago/London: The University of Chicago Press.

Lebedev A (1985) The Cosmos as a Stadium: Agonistic Metaphors in Heraclitus' Cosmology. Phronesis 30(2): 131-150. Netherlands: Brill Academic Publishers. doi: https://doi.org/10.1163/156852885X00020.

Locke J (1979) An Essay Concerning Human Understanding. Oxford: Oxford University Press.

Long A, Sedley D (Eds.) (1987) The Hellenistic Philosophers, vol. 1. Cambridge: Cambridge University Press.

Melchior-Bonnet S (2002) The Mirror: A History. New York/London: Psychology Press.

Miura (2011) The Pictorial World of Henri Fantin-Latour. In Les peintres français $d u$ XIXème siècle: Manet et Fantin-Latour, pp. 81-120. Tokyo: Tokyo University Press.

NIV-New International Version of the Holy Bible (1984) Colorado Springs: International Bible Society.

Nietzsche F (1873/1989) On Truth and Lying in An Extra-Moral Sense. In SL Gilman, C Blair, DJ Parent (Eds.), Friedrich Nietzsche on Rhetoric and Language, pp. 246-257. Oxford: Oxford University Press.

Nietzsche F (2015) Delphi Works of Friedrich Nietzsche. Translated by JM Kennedy. Hastings, UK: Delphi Classics. 
Olk C (2014) Virginia Woolf and the Aesthetics of Vision. Berlin/Boston: Walter de Gruyter.

EDO-Etymology Dictionary Online. Retrieved from https://bit.ly/2WX6jYt.

Orr J (1915) The International Standard Bible Encyclopedia. Chicago: The Howard Severance Co.

Pepper S (1942) World Hypotheses: A Study in Evidence. Berkley: University of California Press.

Plato (2000). The Republic. Translated by T Griffith. P Steinberger (Eds.). Indianapolis: Hackett Publishing Inc.

Pushkin AS (1973) The Tale of the Dead Princess and the Seven Knights. Translated by P Tempest. Moscow: Progress Publishers.

Ricoeur P (1975) The Rule of Metaphor, The creation of Meaning in Language. London and New York: Routledge Classics.

Seneca Lucius Annaeus (2007) Selected Philosophical Letters. Translated by B Inwood. Oxford: Oxford University Press.

Seneca Lucius Annaeus (2014) Delphi Complete Works of Seneca the Younger. Translated by JF Miller. Hastings, UK: Delphi Classics.

Thakur NC (1965) The symbolism of Virginia Woolf. Oxford: Oxford University Press.

WUD-Webster's Revised Unabridged Dictionary. Retrieved from https://bit.ly/32hiC2N.

Wippel J (1989) Truth in Thomas Aquinas. The Review of Metaphysics 43(2): 295-326. Retrieved from https://bit.ly/36G4tiM

Woolf V (1925) Montaigne. The Common Reader. New York: Harcourt, Brace, \& World.

Woolf V (1927) To the Lighthouse. Retrieved from https://researchguides.uic.edu/ebooks.

Woolf V (1928) Orlando. London: Wordsworth Classics.

Woolf V (1929a) A Room of One's Own. London: Penguin Books.

Woolf V (1929b) The Lady in the Looking Glass: A Reflection. Selected Short Stories. London: Penguin Books.

Woolf V (1931) The Waves. Retrieved from https://bit.ly/33lJFvd.

Woolf V (1937) Craftsmanship. The Death of the Moth, and Other Essays. Retrieved from https://bit.ly/36Gavjp.

Woolf V (1941) Between the Acts. London: Vintage Books.

Young D (1986) The Mythological Element in Virginia Woolf's The Waves: Bernard's Vision. Iowa Journal of Literary Studies 7: 94-104.

Zlatev J (2012) Cognitive Semiotics: An emerging field for the transdisciplinary study of meaning. The Public Journal of Semiotics IV(1): 2-24. 
